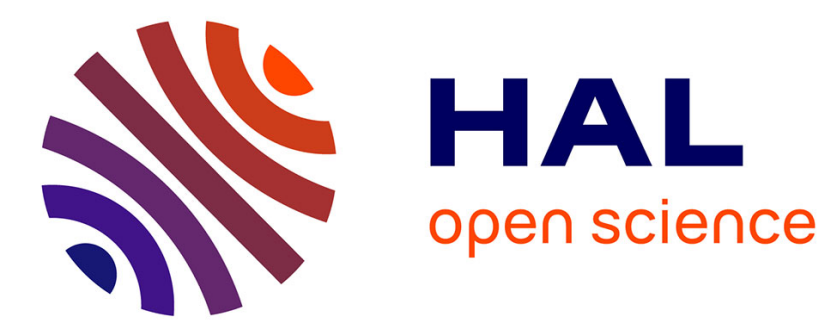

\title{
Nutrition affects longevity and gene expression in honey bee (Apis mellifera) workers
}

\author{
Huan Wang, Shao-Wu Zhang, Zhi-Jiang Zeng, Wei-Yu Yan
}

\section{To cite this version:}

Huan Wang, Shao-Wu Zhang, Zhi-Jiang Zeng, Wei-Yu Yan. Nutrition affects longevity and gene expression in honey bee (Apis mellifera) workers. Apidologie, 2014, 45 (5), pp.618-625. 10.1007/s13592014-0276-3 . hal-01234758

\section{HAL Id: hal-01234758 \\ https://hal.science/hal-01234758}

Submitted on 27 Nov 2015

HAL is a multi-disciplinary open access archive for the deposit and dissemination of scientific research documents, whether they are published or not. The documents may come from teaching and research institutions in France or abroad, or from public or private research centers.
L'archive ouverte pluridisciplinaire HAL, est destinée au dépôt et à la diffusion de documents scientifiques de niveau recherche, publiés ou non, émanant des établissements d'enseignement et de recherche français ou étrangers, des laboratoires publics ou privés. 


\title{
Nutrition affects longevity and gene expression in honey bee (Apis mellifera) workers
}

\author{
Huan WANG $^{1,3}$, Shao-Wu ZHANG ${ }^{2}$, Zhi-Jiang ZENG ${ }^{1}$, Wei-Yu YAN ${ }^{1}$

\footnotetext{
${ }^{1}$ Honeybee Research Institute, Jiangxi Agricultural University, Nanchang 330045, People's Republic of China Canberra, ACT 0200, Australia
} \\ ${ }^{2}$ ARC Center of Excellence in Vision Science, Research School of Biology, The Australian National University, \\ ${ }^{3}$ Institute of Information on Science and Technology of Agriculture, Beijing Academy of Agriculture and Forestry \\ Sciences, Beijing 100097, People's Republic of China
}

Received 28 August 2013 - Revised 7 December 2013 - Accepted 5 February 2014

\begin{abstract}
Nutrition is a major factor affecting animal health, resistance to disease, and survival. In honey bees (Apis mellifera), nectar or honey (carbohydrates) is the energy source, while pollen, which is the sole dietary source of protein, is essential for both larval and adult development. Royal jelly (RJ), a secretion from workers with high protein content, plays a critical role in which queens are fed throughout their lives, is responsible for switching the worker phenotype into the queen one. The role of RJ in extending the lifespan of caged workers is not clear. In this study, we determined longevity of caged workers fed with different diets (carbohydrate only, pollen, and pollen+ RJ) and also expression of six genes in these bees. We found that workers fed with pollen and royal jelly together $(\mathrm{P}+\mathrm{RJ}+)$ showed the best survival, followed by workers fed with pollen only $(\mathrm{P}+\mathrm{RJ}-)$, and workers fed with neither pollen nor RJ $(\mathrm{P}-\mathrm{RJ}-$ ) had the shortest life. Pollen only $(\mathrm{P}+\mathrm{RJ}-$ ) and royal jelly together $(\mathrm{P}+\mathrm{RJ}+)$ significantly affected four of the six genes studied. While pollen and royal jelly together $(\mathrm{P}+\mathrm{RJ}+)$ only affected the vitellogenin gene compared to pollen only $(\mathrm{P}+\mathrm{RJ}-)$. These results demonstrate that pollen and RJ extended worker longevity, suggesting that they may improve the nutritional conditions of bees or contain health and longevity-promoting factors. Further analysis of the lifespanextending genes may broaden our understanding of gene network involved in the regulation of longevity.
\end{abstract}

\section{Apis mellifera / royal jelly / pollen / longevity / gene expression}

\section{INTRODUCTION}

Lifespan in metazoans is influenced not only by genetic factors, but also by environmental factors, including temperature, oxygen, food intake, and nutrition. The availability of environmental nutrients is a key determinant of organism growth and survival. A deficient or improper diet can have negative consequences on health and susceptibility to a variety of pathogens ( $\mathrm{Li}$ et al. 2007).

Corresponding author: W.-Y. Yan, ywygood-0216@163.com

Manuscript editor: David Tarpy
The honey bee (Apis mellifera) is an important model for such studies, because its dietary requirements are well-known. Nectar or honey (carbohydrates) is the energy source, while pollen provides the nutrients required for their internal organ development (Haydak 1970). Protein constitutes 2.5 to $61 \%$ of the dry mass of pollen (Roulston and Cane 2000), which is virtually the only source of protein naturally available to honey bees. Nutrients reported from pollen also include lipids (1-20\%), amino acids, starch, sterols, vitamins, and minerals (Roulston and Cane 2000). Together, these molecules combine to make pollen nutrition one of the most important factors influencing the longevity of newly-emerged bees. 
Royal jelly (RJ) is a secretion produced by nurses with glandular products from mandibular glands and hypopharyngeal glands. RJ is composed of water, proteins, sugars, lipids, vitamins, and free amino acids (Sabatini et al. 2009). In addition, RJ contains a variety of bioactive substances, including AMP N1-oxide, peptides, acetylcholine, and fatty acids, such as 10-hydroxy-2-decenoic acid (10HDA) (Blue et al. 1959). RJ is reported to extend the lifespan of Drosophila (Kamakura 2011), mice (Inoue et al. 2003), and nematode C. elegans (Honda et al. 2011) with artificial feeding. This suggests that royal jelly contains longevitypromoting agents (Alaux et al. 2011).

How pollen affects honey bee health has been well studied (reviewed by Huang (2012)). Besides significantly extending the lifespan of worker honey bees, pollen has been shown to increase the resistance of honey bees to Nosema apis and deformed wing virus, reduce sensitivity to pesticides, and increase the expression of genes affecting longevity and those coding for antimicrobial peptides.

However, the proper amount of protein to caged bees is not clear. Herbert et al. (1977) found that caged bees fed with a high protein diet $(50 \%)$ showed a higher mortality than did those fed less protein (5 and $10 \%)$. They concluded that the high mortality might be due to excessive protein resulting in an inability of bees to defecate (Human et al. 2007). Similarly, Lin and Winston (1998) observed that all bees fed with $100 \%$ royal jelly died within 3 days in cages. They also suspected the inability to defecation as the cause of death, but it might be also due to the fact that RJ alone does not provide enough carbohydrate to supply enough energy and the bees died as a result of starvation. More recently, Pirk et al. (2010) also found that bees survived best with a diet containing no protein. The protein showed the same effect whether they were provided to bees as casein, pollen, or RJ.

In this study, we determined the lifespan and their gene expression of workers fed with different protein diets. The genes we selected include hdacl, Sir2, Superoxide dismutase (Sod), superoxide dismutase 2 (Sod2), thioredoxin reductase 1 (Trxr-1), and Vitellogenin (Vg). Silent information regulator 2 (Sir2) and histone deacetylase 1(hdac1) are two members of histone deacetylation regulators, and they affect longevity in Drosophila, yeast, and Caenorhabditis elegans (Chang and Min 2002). Superoxide dismutase (Sod), superoxide dismutase $2(\operatorname{Sod} 2)$, and thioredoxin reductase 1 (Trxr-1) (Orr and Sohal 1994; Parkes et al. 1998; Missirlis et al. 2001) are involved in Drosophila lifespan regulation. Vitellogenin $(V g)$ expression was known to be affected by nutrition in honey bees (Alaux et al. 2011; Cremonez et al. 1998).

\section{MATERIALS AND METHODS}

\subsection{Bees and diets}

The experiment was performed with the Western honey bee, A. mellifera. In order to obtain a large number of bees of the same age, a naturally mated queen was placed in a queen cage to stop egg-laying for 5 days. Then, the queen was transferred to a queen excluder box for $24 \mathrm{~h}$ or less with an empty frame. The brood produced by the queen on this frame were of the same ages $(<24 \mathrm{~h}$ difference). Three weeks after the queen laid eggs, the frame was removed from the colony and placed in a frame cage in the incubator (dark, $32{ }^{\circ} \mathrm{C}$ and $70 \% \mathrm{RH}$ ). After bees emerged, we divided them equally into three cages (cage size $140 \times 150 \times 220 \mathrm{~mm}, \mathrm{~N} \sim 200$ bees per cage $=21 \mathrm{~g}$ ). All three cages of bees were fed ad libitum with a solution made of $30 \%$ honey, $70 \%$ powdered sugar, and water. One cage ( $\mathrm{P}-\mathrm{RJ}-)$ received no protein at all, with neither pollen nor royal jelly. A second cage ( $\mathrm{P}+\mathrm{RJ}-$ ) was provided with a pollen diet (bee-collected pollen from Camellia sinensis, dried and ground into powder, and mixed with water, $\sim 5 \mathrm{~g} /$ cage), without RJ. The third cage $(\mathrm{P}+\mathrm{RJ}+)$ received both pollen and a royal jelly diet $(50 \%$ pollen and $50 \% \mathrm{RJ}, 5 \mathrm{~g}$ of pollen diet and $5 \mathrm{~g}$ of freshly collected RJ mixed together). We replicated this experiment using four different colonies. The food was replaced every day and records were kept of mortality in each group.

\subsection{Reverse transcription PCR}

We repeated the same experiment ( 3 treatments $\times 4$ colonies) for providing bees for real time PCR 
analysis. Bees from each group were flash frozen in liquid nitrogen at the age of 8 days because pollen consumption diminishes when bees are 8-10 days old (Crailsheim et al. 1992). For RT-PCR, 3 samples per cage were collected, and 4 bees were pooled during RNA extraction for each sample. Thus with 4 replicates we have 12 samples per treatment, and 36 samples for the whole experiment.

RT-PCR was performed on six genes (hdacl, Sir2, Sod, Sod2, Trxr-1 and $V g$ ). RNA integrity was determined by agarose gel (1\%) electrophoresis and ethidium bromide staining. The purity and concentration of each RNA sample was measured in triplicate using a UV spectrophotometer (GeneQuant, Pharmacia). The RNA sample was standardized to $1 \mathrm{ng} / \mu \mathrm{l}$ for reverse transcription. cDNA was synthesized using MLV reverse transcriptase (Takara, Japan) according to the manufacturer's instructions, and GAPDH-1 was used as an internal control. Primer sequences, which were designed by Primer 5.0 software, are listed in Table I. The cycling conditions were as follows: preliminary $94{ }^{\circ} \mathrm{C}$ for $2 \mathrm{~min}, 40$ cycles consisting of $94{ }^{\circ} \mathrm{C}$ for $15 \mathrm{~s}, 63{ }^{\circ} \mathrm{C}$ for $30 \mathrm{~s}$ per cycle, and $72{ }^{\circ} \mathrm{C}$ for $30 \mathrm{~s}$. The specificity of the PCR products was verified by melting curve analysis for each sample. The control and target unigene for each sample were run in the same plate to eliminate interplate variation. The $\mathrm{Ct}$ value for each biological replicate was obtained by calculating the arithmetic mean of three technical replicate values. The relative expression level among the three groups was calculated according to Liu and Saint (2002).

\subsection{Statistical analyses}

We calculated Kaplan-Meier (product-limit) survival estimates for the three nutrition treatments (Kleinbaum and Mitchel 1996). We tested for differences in survival among the three groups using the log-rank and Wilcoxon tests using the statistics software SPSS 16.0. Wilcoxon tests are more sensitive to differences in survival occurring earlier in the trials, while log-rank tests are more sensitive to differences occurring later (Martinez and Naranjo 2010). Results of both tests were consistent in every case, and so we report below only the log-rank test results. Relative expression levels among groups were square root transformed to achieve normality and calculated using the formula presented in Liu and Saint (2002). Genes showing significant differences in expression level were further analyzed by ANOVA, using SPSS 16.0.

Table I. Description of primer sequences and genes used for qRT-PCR assays

\begin{tabular}{|c|c|c|}
\hline Gene name & Gene ID & $5^{\prime}$ to $3^{\prime}$ \\
\hline \multirow[t]{2}{*}{$V g$} & \multirow[t]{2}{*}{ GB13999 } & Forward TTGACCAAGACAAGCGGAACT \\
\hline & & Reverse AAGGTTCGAATTAACGATGAA \\
\hline \multirow[t]{2}{*}{ Sod } & \multirow[t]{2}{*}{ GB10133 } & Forward GTCGTTCCGTGTAGTCGAGAA \\
\hline & & Reverse TCCTTTGACTTCACCCTGAAGA \\
\hline \multirow[t]{2}{*}{ Sod 2} & \multirow[t]{2}{*}{ GB14346 } & Reverse GGTGGTGGTCATTTGAATCATTC \\
\hline & & Forward AAGAAGTGCAGCGTCTGGTTTAC \\
\hline \multirow[t]{2}{*}{ Trxr-1 } & \multirow[t]{2}{*}{ GB17503 } & Forward GATAAACAACAGATTCCACC \\
\hline & & Reverse GAAATATGCAAGAACCGA \\
\hline \multirow[t]{2}{*}{ Sir2 } & \multirow[t]{2}{*}{ GB16265 } & Forward TGGCGAAGGACTTCCGGATGC \\
\hline & & Reverse TGCTACTGGCCGGACCTTCA \\
\hline \multirow[t]{2}{*}{ Hdacl(rpd3) } & \multirow[t]{2}{*}{ GB14706 } & Forward GGTTCTGTAGCTGCTGCGGTGA \\
\hline & & Reverse GGCATGATGTAAACCACCACCCC \\
\hline \multirow[t]{2}{*}{ GAPDH 1} & \multirow[t]{2}{*}{ GB11613 } & Forward GCTGGTTTCATCGATGGTTT \\
\hline & & Reverse ACGATTTCGACCACCGTAAC \\
\hline
\end{tabular}




\section{RESULTS}

\subsection{Survival of bees fed with different diets}

Bees fed with pollen and royal jelly together $(\mathrm{P}+\mathrm{RJ}+)$ showed the best survival compared to bees fed with pollen only $(\mathrm{P}+\mathrm{RJ}-)$ or with neither pollen nor RJ (P- RJ-). In addition, bees fed with pollen only (P+ RJ-) also survived better than those with neither pollen nor RJ (P- RJ-) (Figure 1). Log-rank tests of survival time indicated that bees fed with three different diets differed significantly in terms of average lifespan $\left(X^{2}=684.67, P<0.0001\right)$ (Table II).

\subsection{Relative gene expression in worker abdomens}

Bees fed with pollen and royal jelly together $(\mathrm{P}+$ $\mathrm{RJ}+$ ) and bees fed with pollen only $(\mathrm{P}+\mathrm{RJ}-)$ both had a higher expression of $V g$ than those fed without pollen and $\mathrm{RJ}(\mathrm{P}-\mathrm{RJ}-)$. Bees fed with pollen and royal jelly together $(\mathrm{P}+\mathrm{RJ}+)$ also had a higher expression level of $V g$ than bees fed with pollen only $(\mathrm{P}+\mathrm{RJ}-)$. The expression levels of Sod and trxr-1 were higher in bees fed with pollen and royal jelly together $(\mathrm{P}+\mathrm{RJ}+)$ and bees fed with pollen only $(\mathrm{P}+\mathrm{RJ}-)$ than those fed with neither pollen nor $\mathrm{RJ}(\mathrm{P}-\mathrm{RJ}-)$, but the former two higher groups were not significantly different from each other. Bees fed with pollen and royal jelly together $(\mathrm{P}+\mathrm{RJ}+)$ and bees fed with pollen only $(\mathrm{P}+\mathrm{RJ}-)$ both had lower expression levels than those fed without pollen and RJ (P- RJ-) in hdacl. Two other genes (Sir2, Sod2) were not significantly different among three groups (Figure 2).

\section{DISCUSSION}

The main finding in this study is that bees fed with pollen and royal jelly together $(\mathrm{P}+\mathrm{RJ}+)$ showed the best survival, followed by bees fed with pollen only $(\mathrm{P}+\mathrm{RJ}-)$, and bees fed with neither pollen nor RJ (P- RJ-) had the shortest life. Schmidt et al. (1987) found that the major factor affecting the life span of caged bees was the total amount of protein ingested. Protein-rich $(>26 \%)$ pollen of Camellia sinensis contains 10 essential amino acids: lysine, tryptophan, phenylalanine, methionine, threonine, leucine, isoleucine, valine, arginine, and histidine (Su et al. 2000; Li 2003), which are required for their growth and development

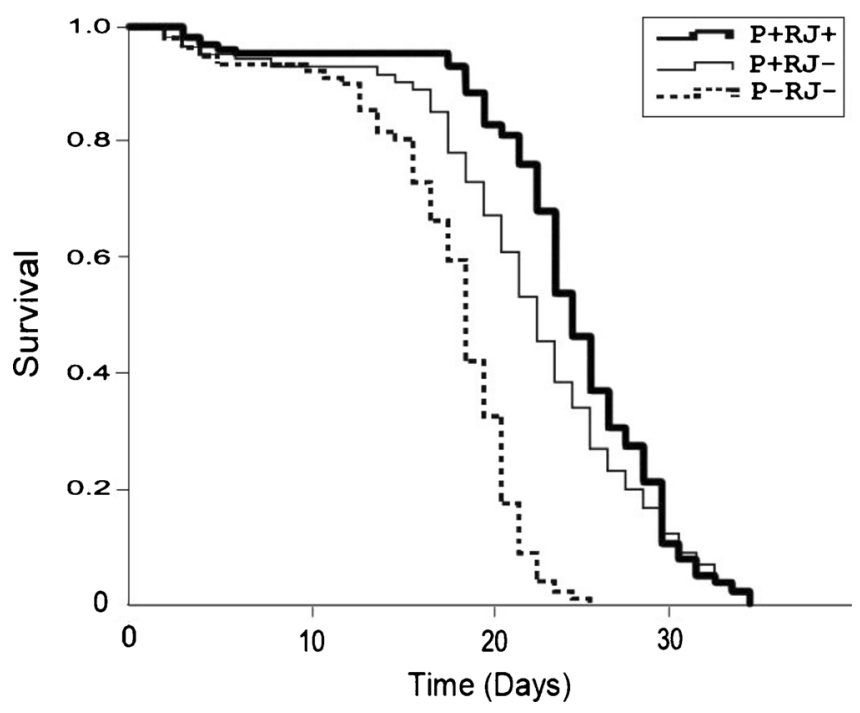

Figure 1. Survival of bees fed three different diets, pooled for all colonies $(n=4)$ for reasons of clarity. Bees were fed with pollen and royal jelly together $(\mathrm{P}+\mathrm{RJ}+)$, pollen only $(\mathrm{P}+\mathrm{RJ}-)$ and with neither pollen nor $\mathrm{RJ}(\mathrm{P}-\mathrm{RJ}-)$. 
Table II. Life span (days) of worker bees fed with different diets

\begin{tabular}{lccc}
\hline Treatment & Mean (SE) & Median & $\begin{array}{c}\text { Sample } \\
\text { size }\end{array}$ \\
\hline P+ RJ+ & $24.79(0.211)^{\mathrm{A}}$ & 24 & 806 \\
P+ RJ- & $22.67(0.251)^{\mathrm{B}}$ & 22 & 782 \\
P- RJ- & $17.89(0.174)^{\mathrm{C}}$ & 17 & 798 \\
\hline
\end{tabular}

Different letters indicate significant difference $(P<0.05)$ of log-rank tests among the treatments. Sample sizes varied slightly because we used weight of bees initially, but mortality record allowed us to know the precise bee numbers later

(de Groot 1953). It may explain the better survival from pollen $\operatorname{diet}(\mathrm{P}+\mathrm{RJ}-)$ than neither pollen nor $\mathrm{RJ}$ $(\mathrm{P}-\mathrm{RJ}-)$. This result was consistent with what was found by Di Pasquale et al. (2013). The mixture of royal jelly and pollen prolonged the lifespan of workers, suggesting that the addition of royal jelly may provide the essential nutritional components for optimal survival, or royal jelly may play a life spanextending function, as reported in some species across phyla (Kamakura 2011; Inoue et al. 2003; Honda et al. 2011). Royalactin has been reported to induce prolonged longevity in Drosophila (Kamakura 2011), and it may also have important role in the longevity in caged workers. Because workers did not consume those with $\mathrm{RJ}$ alone $(\mathrm{P}-$ $\mathrm{RJ}+$ ) in the preexperiment, we did not have this treatment. However, our data suggest that the effects of pollen and RJ are additive.

Our results are not consistent with those of Pirk et al. (2010) which showed that bees fed with carbohydrate only survived better than bees provided protein mixed with sugar, whether the protein was provided as casein, pollen, or RJ. In fact, their results contradicted earlier studies which showed that pollen always helped worker bees survive better in caged bees (Rinderer and Dell 1977). The most likely reason is that Pirk et al. (2010) gave bees a mixture of protein and carbohydrate, while in these earlier studies and our current study, we provided

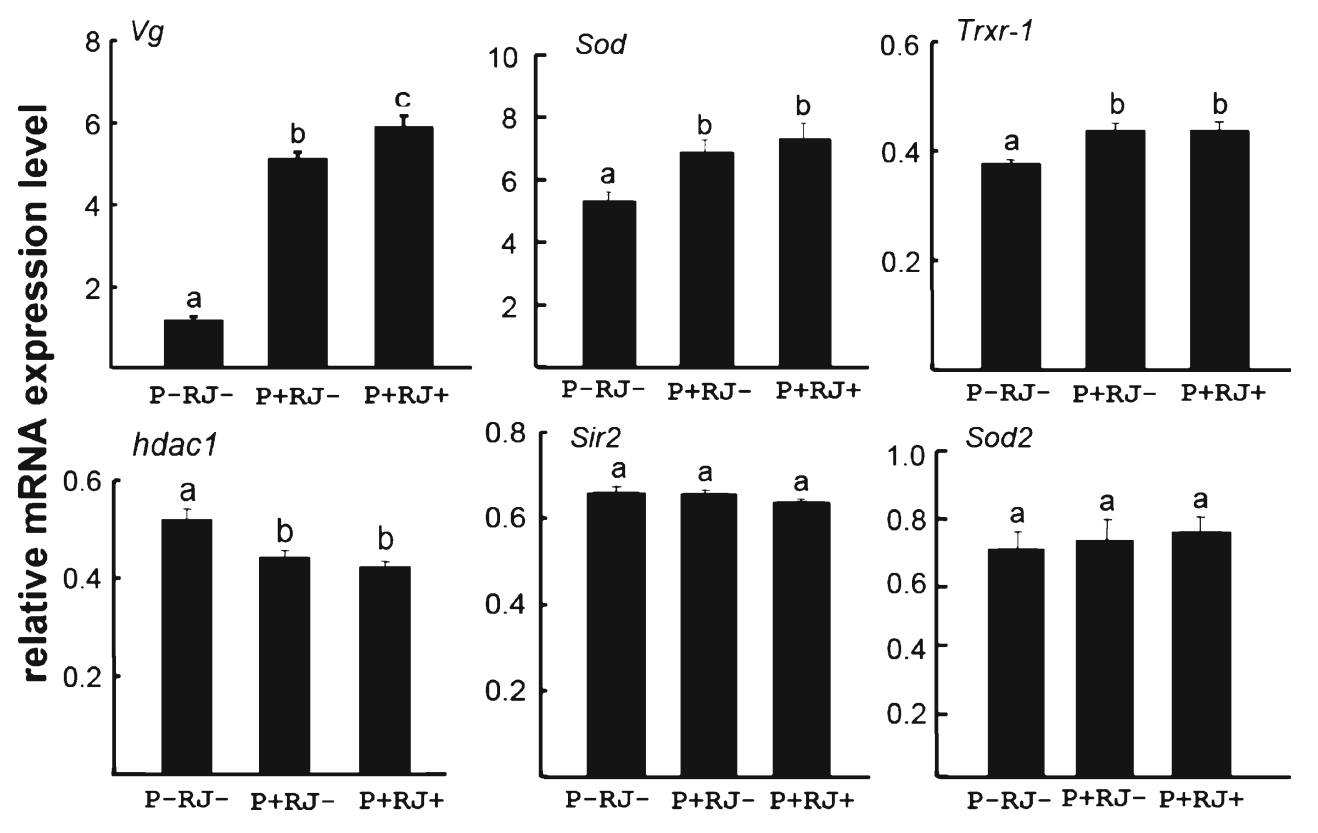

Figure 2. Expression levels of six genes relative to a reference gene GAPDH-1 in the different nutrition group. Different letters on top of bars indicate significant difference $(P<0.05)$ between the groups. Relative expression data were transformed by square root transformation and presented hereafter transformation. Genes showing significant differences in expression level were further analyzed by ANOVA, using SPSS 16.0. Each bar corresponds to a single group represented as the mean \pm S.E of its biological replicates. 
bees with protein and carbohydrate separately. It is possible that when bees are forced to eat the mixture to obtain enough carbohydrate for energy needs, excessive proteins might become toxic or indigestible to bees. When carbohydrate in the mixture is extremely low (e.g., when only RJ was provided), bees will starve because they cannot obtain enough carbohydrate from pure RJ, therefore they die due to starvation. This was observed in the Pirk et al. (2010) study where bees died in 5 days when RJ or pollen was provided to bees at a 3:1 ratio to sugar and in an earlier study where bees with pure RJ died within 3 days (Lin and Winston 1998).

We studied the expression of six genes and found an increase in $V g$ level with a richer diet. Bees fed with pollen and royal jelly diet $(\mathrm{P}+$ $\mathrm{RJ}+$ ) had the highest $V g$ level, followed by those fed with pollen alone $(\mathrm{P}+\mathrm{RJ}-)$, and finally those with no protein in their food ( $\mathrm{P}-$ $\mathrm{RJ}-)$. The effect of pollen and RJ on $V g$ expression was similar to their effect on longevity: RJ and pollen further increased $V g$ expression, which was higher than the control (no protein). $V g$ is a female-specific glycolipoprotein synthesized in the fat body and transported to the ovaries and other body tissues (Corona et al. 2007). It is a yolk protein taken up by developing oocytes and is associated with egg production in queens. It also has antioxidant functions that protect bees from oxidative stress and enhance longevity (Seehuus et al. 2006). Seehuus et al. (2006) showed that bees with higher $V g$ expression survived longer after paraquat injection, and $V g$ knockdown by RNAi treatment significantly shortened lifespan. Corona et al. (2007) proposed that low $\mathrm{JH}$ levels induce $V g$ expression and proposed a negative feedback loop linking high $\mathrm{Vg}$ with repression of the IIS pathway, both of which contribute to long life and high fecundity in queen bees. Therefore, $V g$ level can be potentially an indicator of longevity.

However, none of the other five genes followed this pattern. Three genes ( $h d a c 1$, Sod, Trxr-1) showed significant changes when bees were fed with pollen but did not improve further with the additional protein from RJ. The other two genes (Sir2 and Sod2) did not respond to either pollen or pollen and RJ. The responses of Sod, Sod2, and Trxr-1 in our study were similar to Alaux et al. (2011), who also found that Sod and Trxr-1 were upregulated in bees fed with pollen, but Sod2 showed no response. Crossspecies analyses of vertebrates have found that high antioxidant levels and longevity are not positively correlated (Perez-Campo et al. 1998). In honey bees, queen longevity is also not linked to increased antioxidant gene expression (Corona et al. 2005).

We expected that the expression patterns of hdacl and Sir2 in honey bee would be similar to trends observed in $C$. elegans and Drosophila. Indeed, hdacl was the highest in the control (no protein) and was significantly reduced in bees fed pollen or pollen $+\mathrm{RJ}$. This fits the prediction based on results from $C$. elegans and Drosophila (Chang and Min 2002) because this gene is considered an aging gene. However, expression of Sir2 in the abdomen was not significantly different among three groups. How these genes affect honey bee longevity is not clear at this time, and it will be the subject of future research.

\section{ACKNOWLEDGMENTS}

We thank Fei Zhang and Zhenxiu Zeng for help with beekeeping. We are grateful to Huang Z.Y. for improving this manuscript. This work was supported by the Earmarked Fund for China Agriculture Research System (No. CARS-45-KXJ12) and the National Natural Science Foundation of China (No. 31160486, No. 31260524).

La nutrition influence la longévité et l'expression génique chez les ouvrières d'abeilles (Apis mellifera)

Gelée royale / pollen / essai en laboratoire / santé des abeilles / durée de vie

Die Ernährung beeinflusst Lebensdauer und Genexpression bei Arbeiterinnen der Honigbiene (Apis mellifera)

Apis mellifera / Gelee royale / Pollen / Lebensdauer / Genexpression 


\section{REFERENCES}

Alaux, C., Christelle, D., Hughes, P., Yves, L.C. (2011) Nutrigenomics in honey bees: digital gene expression analysis of pollen's nutritive effects on healthy and varroa-parasitized bees. BMC genomics. 12, 496

Blue, M.S., Novak, A.F., Taber, S. (1959) 10-hydroxy-2decenoic acid, an antibiotic found in royal jelly. Science. 130, 452-453

Chang, K.T., Min, K.T. (2002) Regulation of lifespan by histone deacetylase [J]. Ageing Res Rev. 1(3), 313-326

Corona, M., Hughes, K.A., Weaver, D.B., Robinson, G.E. (2005) Gene expression patterns associated with queen honey bee longevity. Mech Ageing Dev. 126(11), 1230-1238

Corona, M., Velarde, R.A., Remolina, S., Moran-Lauter, A., Wang, Y., Hughes, K.A., Robinson, G.E. (2007) Vitellogenin, juvenile hormone, insulin signaling, and queen honey bee longevity. Proc. Natl Acad. Sci. USA 104, 7128-7133

Crailsheim, K., Schneider, L., Hrassnigg, N., Bühlmann, G., Brosch, U., Gmeinbauer, R. (1992) Pollen consumption and utilization in worker honeybees (Apis mellifera carnica): Dependence on individual age and function. J Insect Physiol 38, 409-419

Cremonez, T.M., De Jong, D., Bitondi, M.M.G. (1998) Quantification of hemolymph proteins as a fast method for testing protein diets for honey bees (Hymenoptera:Apidae). J Econ Entomol. 91(6), 1284-1289

De Groot, A.P. (1953) Protein and amino acid requirements of the honey bee (Apis mellifica L.). Physiol Comp Oecol 3, 197-285

Di Pasquale, G., Salignon, M., Le Conte, Y., Belzunces, L.P., Decourtye, A., Kretzschmar, A., Suchail, S., Brunet, J.L., Alaux, C. (2013) Influence of pollen nutrition on honey bee health: do pollen quality and diversity matter? Plos One 8, 1-13

Haydak, M.H. (1970) Honey bee nutrition. Annu. Rev. Entomol. 15, 143-156

Herbert, E.W., Shimanuki, H., Caron, D. (1977) Optimum protein levels required by honey bees (Hymenoptera, Apidae) to initiate and maintain brood rearing. Apidologie 8, 141-146

Honda, Y., Fujita, Y., Maruyama, H., Araki, Y., Ichihara, K., Sato, A., Kojima, T., Tanaka, M., Nozawa, Y., Ito, M., Honda, M. (2011) Lifespan-extending effects of royal jelly and its related substances on the nematode Caenorhabditis elegans [J]. Plos One. 6(8), e 23527

Huang, Z.Y. (2012) Pollen nutrition affects honey bee stress resistance. Terrestrial Arthropod Reviews 5, 175-189

Human, H., Nicolson, S.W., Strauss, K., Pirk, C.W.W., Dietemann, V. (2007) Influence of pollen quality on ovarian development in honeybees Apis mellife scutellata. J Insect Physiol. 53, 649-655

Inoue, S., Koya-Miyata, S., Ushio, S., Iwaki, K., Ikeda, M., Kurimoto, M. (2003) Royal Jelly prolongs the life span of $\mathrm{C} 3 \mathrm{H} / \mathrm{HeJ}$ mice: correlation with reduced DNA damage. Expl Gerontol. 38, 965-969

Kamakura, M. (2011) Royalactin induces queen differentiation in honeybees. Nature. 473, 478-483

Kleinbaum D. G., Mitchel K. (1996) Statistics for Biology and Health (survival analysis, second edition).Springer science + Business Media, Inc.

Li, J.L. (2003) Studies on the content of amino acids and proteins in tea pollen (Camellia sinensis). J Tea Business. 25(2), 61

Li, P., Yin, Y.L., Li, D., Woo, K.S., Wu, G. (2007) Amino acids and immune function. Br J Nutr 98 , 237-252

Lin, H., Winston, M.L. (1998) The role of nutrition and temperature in the ovarian development of the worker honey bee (Apis mellifera) [J]. Can. Entomol. 130(06), 883-891

Liu, W., Saint, D.A. (2002) A new quantitative method of real time reverse transcription polymerase chain reaction assay based on simulation of polymerase chain reaction kinetics. Anal Biochem. 302, 52-59

Martinez, R.L.M.C., Naranjo, J.D. (2010) A pretest for choosing between longrank and wilcoxon tests in the two-sample problem. Int. J. Stat. 48(2), 111-125

Missirlis, F., Phillips, J.P., Jäckle, H. (2001) Cooperative action of antioxidant defense systems in Drosophila [J]. Curr Biol. 11(16), 1272-1277

Orr, W.C., Sohal, R.S. (1994) Extension of life span by overexpression of superoxide dismutase and catalase in Drosophila melanogaster. Science 263, 1128-30

Parkes, T.L., Elia, A.J., Dickinson, D., Hilliker, A.J., Phillips, J.P., Boulianne, G.L. (1998) Extension of Drosophila lifespan by overexpression of human SOD1 in motoneurons. Nat Genet 19, 171-4

Perez-Campo, R., Lopez-Torres, M., Cadenas, S., Rojas, C., Barja, G. (1998) The rate of free radical production as a determinant of the rate of aging: evidence from the comparative approach. J Comp Physiol B. 168, 149-158

Pirk, C.W.W., Boodhoo, C., Human, H., Nicolson, S. (2010) The importance of protein type and protein to carbohydrate ratio for survival and ovarian activation of caged honeybees (Apis mellifera scutellata) [J]. Apidologie. 41(1), 6272

Rinderer, T.E., Dell, E.K. (1977) Worker honey bee response to infection with Nosema apis: influence of diet [J]. J Econ. Entomol. 70(4), 431-433 
Roulston, T.H., Cane, J.H. (2000) Pollen nutritional content and digestibility for animals. Plant Syst. Evol 222, 187-209

Sabatini, A.G., Marcazzan, G.L., Caboni, M.F., Bogdanov, S., Almeida-Muradian, L.B. (2009) Quality and standardisation of royal jelly. J. ApiProduct ApiMedical Sci. 1, 1-6

Schmidt, J.O., Thoenes, S.C., Levin, M.D. (1987) Survival of honey bees, Apis mellifera (Hymenop- tera: Apidae), fed various pollen sources. Ann. Entomol. Soc. Am. 80, 176-183

Seehuus, S.C., Norberg, K., Gimsa, U., Krekling, T., Amdam, G.V. (2006) Reproductive protein protects functionally sterile honey bee workers from oxidative stress. Proc. Natl Acad. Sci. USA 103, 962-967

Su, S.K., Chen, S.L., Ling, X.Z., HU, F.L., Shao, M., Tong, F.D. (2000) The determination of ingredient of tea (Camellia sinensis) pollen. Apic.China 51(2), 3-5 